\title{
Aquaculture as a potential support of marine aquarium fish trade sustainability
}

\author{
L. Molina \& A. Segade \\ Grupo de Investigación en Acuicultura, ULPGC \& ICCM, Telde, \\ Canary Islands, Spain
}

\begin{abstract}
Recently, the popularity of aquariums has been increasing. As a result, the aquarium industry as a whole is of a relatively low volume yet has a very high value.

Unlike freshwater aquarium species, for which $90 \%$ of species are currently farmed, the great majority of marine aquaria are stocked with wild species caught mainly from coral reefs and adjacent habitats. These fisheries, in addition to other activities, have contributed to the degradation of coral reef habitats.

Aquaculture had experienced a great deal of development of culture technologies in the last few decades what could be applied to ornamental species. However, the number of cultured species is still limited (1-2\%). The market demand may be satisfied by cultured fish once culture technologies have been established successfully.

The present article presents an overview of the ornamental fish trade regarding the most important species involved and their situation, as well as updated information on breeding protocols for some high-value marine fish species.
\end{abstract}

Keywords: marine ornamental fish, aquarium fish trade, aquaculture.

\section{Marine ornamental fish trade}

To a great extent, the organisation of the ornamental species trade is highly complex and dynamic, concerning about 2 million people worldwide, from collectors to hobbyists. According to Food and Agriculture Organization of the United Nations [1] data, the ornamental species trade represents only $0.5 \%$ of the international fish trade. According FAO data the volume of export increase in 
value from USD 21.5 millions in 1976 to USD 315 millions in 2007 [2]. Besides, this sector plays an important role in providing income and employment, especially in developing countries.

The estimated annual global trade in marine species involves between 20 and 24 million animals [3], it is not possible to calculate the number, only estimate. The ornamental trade also supports a multi-million dollar industry in aquarium tanks, filter systems and other accessories [3]. The biggest exporters are in Southeast Asia (51\% of exports). Europe accounts for 29\%, North America 4\% and South America 6\%. And the biggest importers are United States of America, Japan and some European countries, as Germany, the Netherlands, and Italy [2].

Most marine ornamental fish are harvested from the wild (90-99\%) [4]. Reefs of south-east Asia are the most important source for the aquarium trade, and because of this, they are particularly at risk. Reefs provide important resources for hundreds of millions of people through both local sustenance and commerce [5].

The mortality of tropical organisms prior to reaching the aquarium market $(25-80 \%)$ are associated to a range of factors, including poor or even destructive collection and husbandry practices, stress and poor shipping [2]. Well-managed shipping and husbandry practices based on training can help to diminish these mortality levels [4]. Because of that, various organizations have worked to promote conservations and to develop standard procedures to trade wild specimens, as United Nations Environment Programme (UNEP) and Marine Aquarium Council Certification (MAC). In 1963 the UNEP members adopted the Convention on International Trade in Endangered Species of Wild Fauna and Flora (CITES) to ensure that international trade does not threaten the survival of natural populations. Ornamental fish are not included in CITES, except for Hippocampus spp. MAC provides aquarists and consumers a tool to identify marine aquarium organisms that originate from managed reefs, are caught using non-destructive methods, and are handled and transported according to best practices.

\subsection{Primary fish species in aquarium trade}

Since 2000, some institutions have worked together to establish the Global Marine Aquarium Database (GMAD) as a freely available source of information on the global aquarium industry [4]. The use of the GMAD allows estimates based on quantitative rather than qualitative data, but it cannot be used to calculate net volumes of trade. According to the GMAD, the main marine fish groups traded are Pomacentridae, Acanthuridae, Balistidae, Labridae, Pomacanthidae, Chaetontidae and Syngnathidae (Table 1).

\section{Wild-caught animals and the impact on the ecosystem}

Reefs cover less than $0.25 \%$ of the marine environment; they are considered "the rainforest of the seas", because of their biodiversity. They are considered the 
Table 1: The top ten traded species of ornamental fish worldwide. Data provided by GMAD (Global Marine Aquarium Database).

\begin{tabular}{|c|c|}
\hline \multirow{7}{*}{ Pomacentridae } & Abudefduf spp. \\
\cline { 2 - 2 } & Chrysiptera biocellata \\
\cline { 2 - 2 } & Chrysiptera cyanea \\
\cline { 2 - 2 } & Amphiprion bicinctus \\
\cline { 2 - 2 } & Amphiprion frenatus \\
\cline { 2 - 2 } & Amphiprion ocellaris \\
\cline { 2 - 2 } & Amphiprion sebae \\
\hline Labridae & Labroides dimidiatus \\
\hline Chaetodontidae & Heniochus acuminatus \\
\hline Acanthuridae & Paracanthurus hepatus \\
\hline
\end{tabular}

most biologically and productive ecosystems of the world, coral reefs support over 4000 species of fish, approximately 800 species of coral [6] and a great number of other invertebrates. Additionally, a large number of species use these ecosystems as reproduction or husbandry areas.

The threats affecting coral reefs are large, between them ornamental fisheries collection may often be one of the extractive activities. Moreover, destructive fishing techniques, such as the use of dynamite, sodium cyanide, or quinaldine, are often used to stun and catch ornamental species [7], promoting severe and long-term damage to target species and to the surrounding habitat. More efforts in producer countries are needed to change their policies, promote awareness campaigns and regulate the importation, distribution and use of cyanide. All of these methods cause severe damage to populations of organisms and also the destruction of vast areas of the coral reef habitat itself. Additionally, these practices have been reported to cause coral and crustacean bleaching in different degrees depending on the dose used [8]. Some friendly collection techniques or devises, such as hand nets, tubular nets, lines with barbless hooks or specially designed devices for collecting particular species have already been used in the Philippines, Indonesia, Australia, Sri Lanka, Hawaii and the Pacific.

Additionally, over-harvesting of organisms known to be fish cleaners [9], can also negatively affect the ecology of reef fish, especially for members of symbiotic relationships, but the impacts remain unknown.

Another issue of concern is the selective collection of juveniles and males due to their distinctive colouration [4]. This is the case for the French angelfish (Pomacanthus paru) and the neon damselfish (Neoglyphidodon oxyodon), in which juveniles are more attractive than adult conspecifics. These selective fisheries may lead to imbalanced populations and ultimately affect recruitment and reproduction.

A special case is the Banggai cardinalfish (Pterapogon kauderni), an endemic species with a much localised distribution, restricted to shallow waters of the Banggai islands, Indonesia. This species is usually associated with Diadema 
setosum and mangroves, in colonies of between 2 and 14 individuals. This fishery has a negative impact on its targeted populations, even when fished with environmentally friendly techniques [10].

To a great extent, the effects of collecting fish for the aquarium trade on ecosystems are still unknown. Some studies show the sustainability of the ornamental fisheries [11]. But these effects should be measured with respect to declines in particular species or at particular locations rather than globally [4]. In general, fish population species with narrow geographical ranges can be the most vulnerable to exploitation, but also depending on the species abundance.

\section{Marine ornamental aquaculture}

The high demand, increasing regulations and the conservation concerns related to the marine ornamental market are factors that emphasise the interest in promoting aquaculture activities for marine ornamental species. Breeding marine ornamental fish can not only provide an alternative supply for the market but also furnish new information on the reproductive biology story of these species, which is critical to understanding the response of natural stocks to anthropogenic effects [12].

The UNEP World Conservation Monitoring Centre Report on the Global Trade in Marine Ornamental Species (2003) reports 69 fish species associated with captive breeding, in sharp contrast with the Marine Fish Breeding Records (MFBR), which reported 575 species [13]. These data showed the differences between successful ornamental fish reproduction rapports and commercially available species (Table 2).

Recent advances in technology, including improvements in feeds for different life cycle stages, will enable more species to be cultured in the industry. However, to date, successful rearing has been scientifically reported for only a few species and less than $1 \%$ of marine aquarium fish are commercially produced [8]. Successful larval rearing mainly concerns reproductive strategies and the size of newly hatched larvae. Key points in breeding these species are related to the spawning types displayed by marine ornamental fish species. The majority of marine ornamental fish species cultured in captivity display large demersal eggs. However, some success has been achieved for pelagic spawners (e.g., Z. flavescens.).

Another important factor is the size of newly hatched larvae, which should be large enough to accept "traditional" live prey types that are commonly employed in food-fish aquaculture. The most common reasons for unsuccessful larval culture are failure in first feeding and inadequate nutritional profiles of the food [14]. Because of these reasons, the early life stage remains a critical bottleneck in marine aquaculture. Larviculture protocols for marine ornamental fish species need to be optimised, especially for commercially important species. Despite the zootechnical breakthroughs that have been achieved in the last few years on the larviculture of some marine ornamental fish, feasible commercial-scale protocols for the mass culture of the most valuable species are still lacking. 
Table 2: $\quad$ Main ornamental fish species bred in captivity.

\begin{tabular}{|c|c|c|}
\hline \multirow{2}{*}{ Acanthuridae } & Zebrasoma flavescens & 1 and 2 \\
\hline & Paracanthurus hepatus & 1 and 2 \\
\hline \multirow[t]{2}{*}{ Pomacentridae } & $\begin{array}{c}\text { Amphiprion ocellaris, A. percula, A. clarkii, A. bicinctus, } \\
\text { A. frenatus, A. melanopus, A. ephippium, A. rubrocinctus, } \\
\text { A. sadaracinos, A. periderion, A. polymnus }\end{array}$ & 3 \\
\hline & Prennas biaculeatus & 3 \\
\hline Pseudochromidae & $\begin{array}{c}\text { Pseudochromis fridmani, } P \text {. flavivertex, } P \text {. albdabraensis, } \\
\text { P. springeri, } P \text {, sankeyi, } P \text {. stenii }\end{array}$ & 3 \\
\hline \multirow{3}{*}{ Gobiidae } & Elacatinus oceanops, E. figaro & 3 \\
\hline & Gobiosoma lousiae, G. punticulatus, G. multifasciatum & 3 \\
\hline & Gobiodon citrinus, G. okinawae & 3 \\
\hline \multirow{5}{*}{ Apogonidae } & Apogon imberbis, A. notatus, A. cianosoma & 1 \\
\hline & Apogon leptacanthus, A. compresses & 3 \\
\hline & Sphaeramia orbicularis & 1 \\
\hline & Pterapogon kaudernii & 3 \\
\hline & Sphaeramia nematoptera & 3 \\
\hline \multirow[t]{2}{*}{ Syngnatidae } & $\begin{array}{c}\text { Hippocampus kuda, H. ingens, } H . \text { subelongatus, } H . \text { breviceps, } \\
\text { H. comes, H. fuscus, H. zosterae, H. abdominalis, H. erectus, } \\
\text { H. reidi, H. trimaculatus }\end{array}$ & 3 \\
\hline & Hippocamopus hippocampus & 1 \\
\hline Blenniidae & Meiacanthus ovalaunensis, M. nigrolineatus & 3 \\
\hline Pomacanthidae & Centropyge sp. & 1 \\
\hline \multirow{3}{*}{ Labridae } & Thalasoma bifasciatum, T. Cupido & 1 \\
\hline & Labroides dimidiatus & 1 \\
\hline & Halichores maculipinna & 1 \\
\hline Plesiopidae & Calloplesiops altivelis & 3 \\
\hline \multirow{2}{*}{ Scianidaea } & Pareques accuminatus, P. umbrosus & 1 \\
\hline & Equetus lanceolatus & 1 \\
\hline
\end{tabular}

1. Subject of research.

2. Captive-raised (captured as post larval stage and grow up in captivity conditions).

3. Commercially available.

Recently, companies have started marketing and selling captive-raised fish, which are captured as post-larvae from the wild and grown to market size in captivity [15]. This system is based on the principle that most marine reef fish species have a pelagic larval stage in their life cycles. Collecting a small percentage of these post-larvae represents a new exploitable and sustainable marine resource. Post-larval collection is not only for developing an innovative and sustainable type of aquaculture but also for repopulation efforts, which are just beginning. 


\subsection{Primary fish farmed species in aquarium trade}

The main families in this group bred for aquarium purposes are Pomacentridae, Pseudochromidae Gobiidae, Apogonidae, and Syngnathidae (Table 2). Other species from different families are currently the topic of research efforts. The present article reviews the available rearing protocols for the main fish species bred for the marine aquarium trade.

\subsubsection{Pomacentridae}

These were the first ornamental fish to be captive-bred, but considering their importance in the aquarium trade (Table 1), a great amount of effort is still being focused on breeding these fish. This family includes damselfish and clownfish.

Protandrous hermaphroditism as well as the presence of amphisexual gonads in juveniles has been documented for most clownfish species [16]. When pairs are selected, they should be stocked separately in tanks with a protective habitat such as flowerpots or PVC pipes [16], which are easy to remove for hatching. Water quality is also an important factor [16]. Diets on broodstocks continue to be one of the least studied subjects in fish nutrition and are limited to a few species. They are usually fed on different diets (frozen, dried or handmade diets) [16]. When adequate environmental and nutritional conditions are provided, clownfish spawn easily in captivity. They display cleaning behaviour before spawning [17]. After spawning, males take care of nests [16]. Before hatching, clutches used to be transferred to larval tanks. Larvae feed on HUFA-enriched rotifers $\left(B\right.$. plicatilis) until their $10^{\text {rd }}$ day (3-20 rotifers $\left./ \mathrm{ml}\right)$ and on HUFAenriched Artemia nauplii, which are gradually increased from day 5 to day 7 (225 nauplii/ml) depending on species.

Damselfish have been cultured using similar protocols to clownfish [18]. The best procedure to establish a culture is to stock sexually mature damselfish 2.3 $3.5 \mathrm{~cm}$ long together and to separate pairs when they are established in similar conditions to clownfish. For this species, the photoperiod and rotifer enrichment are essential for larval rearing [18].

\subsubsection{Pseudochromidae}

The members of this group are actually subdivided into four subfamilies, including 16 genera and more than 70 species [19] and they are distributed from the Red Sea to the Pacific Ocean. The most famous members of this family are dottybacks. Some of the species of this group are being reproduced in captivity (Table 2).

Most of these species show sequential hermaphroditism, often showing sexual dimorphism and dichromatism. Breeding pairs should be stocked in aquaria under the following conditions: water temperature must be around $27^{\circ} \mathrm{C}$, with a $\mathrm{pH}$ between $8-8.2$, a salinity of $30 \mathrm{ppm}$ and a photoperiod of $14 \mathrm{~h}$ of light, with PVC pipes placed in the tank as a spawning substrate. [20]. Before spawning, the male accompanies the female to the nest site. Then, parental care is exclusively performed by the male until hatching. If appropriate tank conditions are maintained, spawning occurs every six days. Embryo development for both species lasts $96 \mathrm{~h}$ at $27^{\circ} \mathrm{C}$ [20]. Newly hatched larvae are large enough (3.6- 
$3.8 \mathrm{~cm}$ ), they start feeding the morning after hatching. During larval development, feeding is based on rotifers $(10$ rotifers $/ \mathrm{ml})$ and enriched Artemia nauplii (8 nauplii/ml).

\subsubsection{Gobiidae}

The family Gobiidae is one of the largest families of fish, with more than 2,000 species in more than 200 genera [20]. Most gobies are relatively small and feed on small invertebrates. Some of them have cleaner habits. Several species have been spawned in captivity [20] (Table 2).

Genitors can be easily maintained in tanks with conditions of $25^{\circ} \mathrm{C}, 30 \mathrm{ppm}$ salinity, a pH of 8.2 and a photoperiod of $13 \mathrm{~h}$ light: $11 \mathrm{~h}$ dark [21]. They feed on a wide variety of food (live, dried, frozen or handmade food). Gobies lay from 10 to a few hundred eggs depending on the species. They spawn inside PVC short pipes placed on the bottom of the tank. Eggs are adhered to the inside of the pipe by the female and fertilised by the male, who usually takes care of the eggs until hatching. Hatching usually occurs in 3-7 days depending on the species and temperature [22]. Before hatching, the PVC tube is usually removed to a larval rearing tank provided with aeration and similar physical-chemical water conditions. Most gobiids reached metamorphosis around day 30 post-hatch [21]. Larvae have been cultured using green water techniques, introducing newly hatched Artemia about 15 days after larval hatching. After this point, dry food may be introduced [22] until reaching adult size.

\subsubsection{Apogonidae}

This family includes 23 genera and 207 species [23]. These fish live in fresh, brackish and sea waters. The most interesting aquarium species inhabit certain Pacific Islands, and they are generally called cardinal fish. Some species are cultured in captivity [24] (Table 2).

Mouthbrooding has been described in this family; in most cases, males are in charge of the egg clutch. To establish a broodstock, a group of 6 or more is simply set up in an aquarium, and they pair temporarily during spawning. The egg clutch contains from 40 to several hundred eggs. Incubation periods for most cardinalfish range from 7 (A. leptacanthus) to 10-12 days (A. margaritophorus). Hatching usually takes place inside the males' mouths, and newly hatched larval sizes range from 2-4 mm, depending on the species. Juveniles leave males' mouths when the yolk sac is completely absorbed. The first feeding usually takes place upon hatching, based on green water techniques or copepods or both. Higher survival rates are observed when HUFA-enriched Artemia are used [101]. The fry are fed with brine shrimp until two months, and after that, they can eat frozen krill. They reach sexual maturity at approximately 9 months.

\subsubsection{Syngnathidae}

Seahorse culture is a quite recent activity in most countries attempting to improve their conservation status [25]. Captive breeding techniques are available only for some species and some of these species are commercially available (Table 2). 
The seahorses are being kept in tanks from 50 to 200 L. In captivity, maintaining seahorses has required the culture of live prey, such as mysid shrimp [14]. These species exhibit courtship regularly performed in pairs. During this process, females transfer eggs to the male pouch. For larval culture, a number of different live prey species have been used [14], resulting in different survival rates. During the first two weeks of life, juveniles exhibit pelagic behaviour [14]. After that, they exhibit benthic behaviour, and at this point, the introduction of an artificial holdfast in aquaria is needed [26]. Survival during this period ranges from 11 to $100 \%[14,26]$.And they become sexually mature, and courtship behaviour starts between three or four months, depending on species.

\subsubsection{Blenniidae}

There are approximately 350 blenny species in the world, spread throughout most of the world's oceans. In general, they reach an average length of 10. Most blennies eat small invertebrates, although some of them eat algae. Some species are bred in captivity (Table 2).

Male blennies guard a small territory, often an empty shell or a rock crevice, where the female enters only to lay eggs that stick to the substratum as they are fertilised. The male then guards the eggs and ventilates them until hatching occurs. Newly hatched larvae can be reared on rotifers and Artemia using green water techniques, but survival is higher using rotifers and wild plankton. Metamorphosis is completed by day 38 .

\subsubsection{Pomacanthidae}

The aquarist interest in this family is based mainly on angelfish. There has been a great effort regarding the culture of these species $[20,27]$. These species are the subject of research (Table 2).

Broodstocks are stocked in groups of 3 to 7 individuals and are fed dried food. Spawning is continuous throughout the year with temperatures of $28^{\circ} \mathrm{C}$ and longer day lengths positively affect spawning activity [28, 29]. Eggs are collected and stocked in larval rearing tanks at $27^{\circ} \mathrm{C}, 31.3 \mathrm{ppm}$ salinity and a $\mathrm{pH}$ of 7.8. The main problem in rearing these species occurs at first feeding due to the small size of newly hatched larvae, making it difficult to feed them on rotifers [12]. Thus, alternative live prey must be used, such as cultured and wild copepods [28].

\subsubsection{Labridae}

The aquarist interest in this family is based mainly on wrasses from the genera Thalassoma, Bodianus, Choris and Labroides. These species are protogynous hermaphrodites, and they produce pelagic eggs daily in numbers from 30 to a few thousand per female. The eggs have diameter sizes from 0.45 to $1.2 \mathrm{~mm}$. Newly hatched larvae range in size from 1.1 to $2.84 \mathrm{~mm}$ depending on the species [20]. Captive spawning has been reported for a number of species [25], but they are still not commercially available (Table 2 ). 


\subsubsection{Plesiopidae}

The most famous member of this family for aquaria purposes is the comet or marine betta, Calloplesiops altivelis. This species lives on coral reefs throughout the Indo-Pacific, usually in caves and crevices along drop-offs. This species has been reared in captivity [30] (Table 2). Females lay from 300 to 500 eggs that are attached together and to the substrate by sticky threads, and both parents take care of the egg clutch. The average size of newly hatched larvae is $3 \mathrm{~mm}$. Larvae are fed rotifers and Artemia, but higher survival rates and better growth have been reported by adding copepod nauplii [12]. Juveniles eat frozen diets three months post-hatching, and their typical pigmentation appears 6 months later.

\subsubsection{Scianidaea}

This family includes approximately 270 species in 70 genera [31] and is commonly known as drums and croakers. It is a highly diverse family of predacious perciform fish. Some species have been spawned and raised in captivity (Table 2 ).

They are gonochoristic, producing pelagic eggs approximately $1 \mathrm{~mm}$ in size; hatching occurs in one day, with 2.5-mm larvae being produced. Larvae are fed enriched rotifers and Artemia using green water techniques. Growth is rapid, and metamorphosis to the juvenile stage occurs 20-25 days after hatching.

\section{Conclusion}

More accurate trade data and more information about natural populations of target species are needed to establish regulations in order to promote the ornamental trade on a sustainable basis. The selection of marine reserves, the establishment of quotas and size limits, and the implementation of ornamental fishery permits based on the resource status and the biological characteristics of target-species are important measures to conserve and properly manage the population stocks of marine ornamental species.

Coral reefs provide important resources for hundreds of millions of people through both local sustenance and commerce. Collecting provides one of the few potentially sustainable local industries in many coastal communities in tropical and subtropical countries with limited resources [26]. Well-managed fishing and husbandry practices can relieve fishing pressure, and provide an alternative livelihood to local people from exporting countries. From a socio-economic point of view, the ornamental trade needs to be equitable, and conflicts between resource users must be minimised.

Aquaculture can provide a growing proportion of marine ornamental fish in the near future. Further research into production technologies for these species must be promoted to diminish the pressure on wild stocks and to increase the effectiveness of aquaculture facilities. These projects should be locally based in source countries as an alternative mode of livelihood for fishing communities, providing employment and generating income with the target objective of integrating conservation and progress. Lessons must be learned from trends and difficulties in the aquaculture of food fish and freshwater ornamental species. 


\section{References}

[1] FAO State of World Fisheries and Aquaculture 2006. Food and Agriculture Organization of the United Nations, Rome. FAO Newsletters. (2007)

[2] Monticini, P. The ornamental fish trade, production and commerce of ornamental fish: technical-managerial and legislative aspects. GLOBEFISH Research Programme. Vol. 102. Rome, FAO 2010. p. 132. (2010)

[3] Rana K. Global trade in ornamental fish. OFI Journal 45: 28-31. (2004)

[4] Wabnitz C., Taylor M., Green E. \& Razak T. From ocean to aquarium. Cambridge, UK. United Nations Environment Programme - World Conservation Monitoring Centre. (2003)0

[5] Molina Dominguez. L., Otero Ferrer, F \& Izquierdo López, M. Coral reefs: threats and future focusing in over-fishing, aquaculture, and educational programs. In: Transactions on Ecology and the environment, Vol., 99 Ed. Wit Press Southampton, United Kingdom. pp. 305-312. (2006)

[6] Paulay G. Diversity \& Distribution of Reef Organisms. Chapman \& Hall, 115 Fifth Ave, NY, NY 1003 (USA) pp: 303-304. (1997)

[7] Sale F. O. Coral reef fishes, dynamic and diversity in a complex ecosystem. London, Academic Press. p. 391-404.

[8] Jones R. \& Steven A. Effects of cyanide on corals in relation to cyanide fishing on reefs. Mar. Freshwat. Res. 48:517-522. (1997).

[9] Woods E. \& Rajasurija A. Sri Lanka Marine Aquarium Fishery Conservation and management issues. Marine Conservation Society and national Aquatic Resources Agency 47 pp. (1999)

[10] Harborne A, Church J., Raines P., Ridley J., Rettie L. \& Walker R. The 1996 Banggai Islands Conservation Project (Central Sulawesi, Indonesia). Coral Cay Conservation, London, UK. 34 pp. (1997)

[11] Bertrand, I. The aquarium fisheries in the Cook Islands. Is there a need for management? SPC Live Reef Fish Information Bulletin 1:10-12. (1996)

[12] Holt G.J. Research on culturing the early life history stages of marine ornamental species In: Marine Ornamental species: Collection, Culture and Conservation. Cato, J.C. and Brown, C.L. Eds. Iowa State Press. pp. 251254. (2003)

[13] Laterveer M. Breeding marine fish-from fantasy to facts, can the marine fish breeding records lift the fog? In: Marine Ornamentals 2004 Culture Collection and Conservation. Honolulu, Hawaii, USA. p.56. (2004)

[14] Otero F., Molina L., Socorro J., Herrera R., Fernández-Palacios H. \& Izquierdo M. Live prey first feeding regimes for short-snouted seahorse Hippocampus hippocampus (Linnaeus, 1758) juveniles. Aquacult. Res. doi:10.1111/j.1345-2109.2010.02505.x 2010. (2010)

[15] Dufour V. J., Jouvenel J. \& Lo, Y. Collecting marine fish and invertebrate larvae: a sustainable technology. In: Abstracts of the First International Conference of Marine Ornamentals. Hawaii. p.27. (1999)

[16] Hoff F. H. Conditioning, spawning, and rearing of fish with emphasis on marine clownfish. Aquaculture consultants Inc. 148 pp. (1996) 
[17] Ross R.M. Reproductive behaviour of anemonefish, A. Melanopus of Guam. Copeia, 917-938. (1978)

[18] Olivotto I., Cardinali M., Barbasresi L. \& Carnevali O. Coral reef fish breeding: the secret of each species. Aquaculture 224, 69-78. (2003)

[19] Gill A.C. Revision of the Indo-Pacific dottyback fish subfamily Pseudochrominae (Perciformes: Pseudochromidae). Smithiana Monograph 1: iii + 1-214, pp. 1-12. (2004)

[20] Olivotto I., Rollo A., Sulpizio R., Avella M., Tosti L. \& Carnevali, O. Breeding and rearing the sunrise dottyback, Pseudochromis flavivertex: The importance of live prey enrichment during larval development. Aquaculture 255, 480-487. (2006a)

[21] Olivotto I., Zenobi A., Rollo A., Migliarini B., Avella M. \& Carnevali, O. Breeding rearing and feeding studies in the cleaner goby Gobiosoma evelynae- Aquaculture 250: 175-182. (2005)

[22] Gardner T \& Van Tassell, J. A system for laboratory of commercial culture of gobiid fishes. SeaScope, 18. ( 2001)

[23] Nelson J.S. Fishes of the World. John Wiley \& Sons, Inc. New York. 624 pp. (1994)

[24] Vagelli A. The reproductive biology and early ontogeny of the mouthbrooding banggai cardinalfish, pterapogon kauderni (perciformes, apogonidae). Environ. Biol. Fishes 56: 79-92. (1999)

[25] Planas M., Chamorro A., Quintas P. \& Vilar A. Establishment and maintenance of threatened long-snouted seahorse, Hippocampus guttulatus, broodstock in captivity. Aquaculture, 283(1-4):19-28. (2008)

[26] Molina L., Socorro J., Herrera R., Otero F., Villares P., Fernández-Palacios H. \& Izquierdo M. Experiencias preliminares del cultivo de Hippocampus hippocampus (Linnaeus, 1758) en Gran Canaria. In: Proceedings of XI Congreso Nacional de Acuicultura (24th-28th September). Vigo, Spain. pp. 47-54. (2007)

[27] Sakai Y., Karino K., Kuwamura T., Nakashima Y. \& Maruo Y. Sexually dichromatic protogynous angelfish, Centropyge ferrugata males can change back to females. Zool. Sciences, 20: 627-633. (2003)

[28] Olivotto I., Holt S., Carnevali O., \& Holt G. Spawning, early development, and first feeding in the lemonpeel angelfish Centropyge flavissimus. Aquaculture 253, 270-278. (2006b)

[29] Holt G.J \& Riley C.M. Laboratory spawning of coral reefs fishes: effects and temperature and photoperiod. 28th U.S. Japan Natural Resources Technical Report no. 28. pp. 33-38. (2001)

[30] Wassink H. Eine gelungene Zucht des Mirakelfisches, Calloplesiops altivelis (Steindachner, 1903). Aquar. Ter. Z. 3:126-130. (1990)

[31] Nelson J.S., Crossman E.J., Espinosa-Pérez H., Findley L.T., Gilbert C.R., Lea R.N., \& Williams J.D. Common and specific names of fishes from the United States, Canada and Mexico. American Fisheries Society, Special 